\title{
Canine periosteal osteosarcoma
}

\section{Osteosarcoma periosteal en perro}

\author{
Gabriela Noronha $\mathrm{T}^{1 *} \mathrm{Ph} . \mathrm{D}$, Julio Edward HM${ }^{2}$ Esp, Rodrigo Casarin Costa ${ }^{1}$ Esp, \\ Rosemeri Oliveira V² Ph.D, Mirela Tinucci C ${ }^{1}$ Ph.D, Andrigo Barboza N ${ }^{1}$ Ph.D.
}

${ }^{1}$ São Paulo State University-UNESP, School of Agrarian and Veterinary Sciences (FCAV), Department of Clinic and Veterinary Surgery, Campus Jaboticabal, SP, Brazil. 2São Paulo State University-UNESP, School of Agrarian and Veterinary Sciences (FCAV), Department of Veterinary Pathology, Campus Jaboticabal, SP, Brazil. *Correspondence: bitoledo@hotmail.com

Received: October 2017; Accepted: May 2018.

\begin{abstract}
Osteosarcoma is the most common bone tumor in dogs. The periosteal osteosarcoma is a subtype of osteosarcoma, and is considered rare in the canine species. The purpose of the present study was to describe a 14-year-old female dog with an ulcerated mass located in the right tibia and 30-days of evolution. The patient was submitted to complementary exams (blood count analysis, dosage of biochemical enzymes - creatinine and alanine aminotransferase, thoracic radiographs, and abdominal ultrasonography) to perform complete staging of the disease. Radiography of the right tibia revealed proliferative and lytic periosteal reaction. The cytological analysis of the mass suggested a round cell tumor. The clinical and the radiological findings indicated the presence of a bone tumor. Pelvic limb amputation was the initial surgical treatment suggested to the client. The histopathological examination revealed the presence of periosteal osteosarcoma with free margins and lymph nodes without evidence of tumor cells. Clinical follow-up was performed through imaging exams without evidence of metastatic disease. The dog had a nine-month survival free time from diagnosis.
\end{abstract}

Keywords: Bone tumor; dog; neoplasia; periosteum; veterinary pathology (Source: MeSH).

\section{RESUMEN}

El osteosarcoma es el tumor óseo más común en los perros. Osteosarcoma periosteal es un subtipo de osteosarcoma y se considera raro en la especie canina. El objetivo del presente estudio fue describir un caso de una perra mestiza de 14 años de edad con una masa ulcerada y localizada en la tibia derecha y 30 días de evolución. Él paciente se sometió a exámenes adicionales (análisis de sangre, dosis de enzimas bioquímicas - creatinina y alanina aminotransferasa, radiografías torácicas y ultrasonografía abdominal) para la estadificacion completa de la enfermedad. La radiografía de la tibia derecha reveló reacción perióstica proliferativa y lítica. Él examen citológico de la masa sugirió un tumor de celulas redondas. La evaluación clínica y hallazgos radiológicos sugieren la presencia de una neoplasia ósea. La amputación de la extremidad pélvica derecha fue el tratamiento quirúrgico inicial sugerido al cliente. Él examen histopatológico reveló la presencia de osteosarcoma periosteal con márgenes libres y ganglios linfáticos sin evidencia de células tumorales. El seguimiento clínico se realizó a través de exámenes de imágenes sin evidencia de enfermedad metastásica. El perra tenía un tiempo de sobrevida de nueve meses desde el diagnóstico.

Palabras clave: Tumor óseo; perro; neoplasia; periostio; patología veterinária (Fuente: MeSH). 


\section{INTRODUCTION}

Osteosarcoma is a malignant mesenchymal tumor that corresponds the most common primary bone tumor in dogs. Due to the implantation ability of the distant tumor cells from the original tumor, the animals affected by this tumor die because of lung metastasis. Regarding all the aspects given, the treatment becomes challenging for Veterinary Oncologists (1).

The periosteal osteosarcoma was described together with other types of osteosarcoma in $1976(2,3)$. This malignant bone tumor has low incidence and is a variant of osteosarcoma. The main lesion of the periosteal osteosarcoma is surface lesion without evidence of medullary involvement. However, some reports have described periosteal osteosarcoma involving the bone marrow $(3,4)$.

Other types of osteosarcoma (parosteal, central and high-grade) develop in the periosteal region but the periosteal osteosarcoma shows distinct anatomical distribution, clinical symptoms, radiographic features and prognostic pattern $(5,6)$.

Periosteal osteosarcoma shows variable imaging appearances at the site of the diaphyseal lesion of the tibia and femur. Several imaging techniques, such as radiography, computed tomography, and magnetic resonance imaging can be used to gather information about periosteal osteosarcoma. All these techniques allow observing changes at the tumor site, tumor size, cortical alterations, spinal involvement and other tumor characteristics (7).

In humans, periosteal osteosarcoma is an intermediate grade chondroblastic osteosarcoma, representing less than $2 \%$ of all osteosarcomas (6). As high-grade osteosarcoma, periosteal osteosarcoma affects young patients and the most frequent locations are tibia $(40 \%)$ and femur $(38 \%)$, followed by humerus $(10 \%)$ and ulna $(5 \%)(7)$. In dogs, the number of cases reported is insufficient to determine the place of incidence (8).

In veterinary medicine, two types of periosteal osteosarcoma have been described in dogs. One form is an aggressive tumor with the same histological characteristics and biological behavior of central osteosarcoma (tumors with central or medullary origin) (8). It may present as asymmetric central osteosarcomas that arise in the spongiosa outer layer of the long bones metaphysis. The second type of periosteal osteosarcoma in dogs is similar to the description found in humans (8).

\section{INTRODUCCIÓN}

El osteosarcoma es un tumor mesenquimal maligno que corresponde al tumor óseo primario más común en perros. Debido a la capacidad de implantación de las células tumorales distantes del tumor original, los animales afectados por este tumor mueren debido a la metástasis pulmonar. En todos los aspectos, el tratamiento se convierte en un reto para los Oncólogos Veterinarios (1).

El osteosarcoma perióstico se describió junto con otros tipos de osteosarcoma en $1976(2,3)$. Este tumor óseo maligno tiene baja incidencia y es una variante del osteosarcoma. La lesión principal del osteosarcoma perióstico es la lesión superficial sin evidencia de compromiso medular. Sin embargo, algunos informes han descrito osteosarcomas periósticos que afectan a la médula ósea $(3,4)$.

Otros tipos de osteosarcoma (parostal, central y de alto grado) se desarrollan en la región perióstica, pero el osteosarcoma perióstico muestra una clara distribución anatómica, síntomas clínicos, características radiográficas y patrón pronóstico $(5,6)$.

El osteosarcoma perióstico muestra apariciones variables por imágenes en el sitio de la lesión diafisaria de la tibia y el fémur. Se pueden utilizar varias técnicas de diagnóstico por imágenes, como la radiografía, la tomografía computarizada y la resonancia magnética, para obtener información sobre el osteosarcoma perióstico. Todas estas técnicas permiten observar cambios en el sitio del tumor, tamaño del tumor, alteraciones corticales, compromiso espinal y otras características del tumor (7).

En humanos, el osteosarcoma perióstico es un osteosarcoma condroblástico de grado intermedio, que representa menos del $2 \%$ de todos los osteosarcomas (6). Como osteosarcoma de alto grado, el osteosarcoma perióstico afecta a pacientes jóvenes y las localizaciones más frecuentes son la tibia ( $40 \%$ ) y el fémur $(38 \%)$, seguidos por el húmero $(10 \%)$ y el cúbito $(5 \%)$ (7). En los perros, el número de casos notificados es insuficiente para determinar el lugar de incidencia (8).

En medicina veterinaria, se han descrito dos tipos de osteosarcoma perióstico en perros. Una forma es un tumor agresivo con las mismas características histológicas y comportamiento biológico del osteosarcoma central (tumores de origen central o medular), (8). Puede presentar como osteosarcomas centrales asimétricos que surgen en la capa externa esponjosa de la metafisis de los huesos largos. El segundo tipo de osteosarcoma perióstico en perros es similar a la descripción encontrada en humanos (8). 
The definition of periosteal osteosarcoma is challenging. An accurate diagnosis requires correlation of the clinical, radiographic, and histopathologic evaluation. It is essential to exclude periosteal osteosarcoma from central osteosarcoma with periosteal extension, highgrade surface osteosarcoma and parosteal osteosarcoma (1).

The histopathological pattern of the central osteosarcoma includes the production of osteoid or immature bone by malignant osteoblasts. However, both the amount and quality of the osteoid matrix can vary highly between tumors (8). The basic characteristic of the high-grade surface osteosarcoma is the fast-growing sarcoma arising from the periosteal tissue $(3,6)$. Histopathologically, parosteal osteosarcoma raises from the outer fibrous layer of the periosteum and reveals characteristics of grade I or II osteoblastic osteosarcoma, resembling fibrous dysplasia (4).

In all types of osteosarcoma, adjuvant chemotherapy may be prescribed to provide pharmacological support after surgical procedures (7). At the same time, the value of adjuvant treatments for periosteal osteosarcoma is unclear $(9,10)$. Consequently, several studies have been performed to assess if the free survival time of dogs with osteosarcoma can be prolonged by adjuvant chemotherapy $(1,4,9,11)$. However, because of the rarity of the tumor, insufficient data are available to support such treatment $(9,12)$. Latest reports showed the efficacy of few cytostatic drugs, such as carboplatin, cisplatin, and doxorubicin (1).

In veterinary oncology, the periosteal osteosarcoma in dogs is poorly described. Equally important, the number of reported cases describing the histopathological findings and survival time is restricted. A descriptive report showing the clinical appearance and diagnosis of this rare tumor in dogs in order to stimulate an accurate investigation was the purpose of this report.

Anamnesis. At the Veterinary Hospital of School of Agrarian and Veterinary Sciences, São Paulo State University (UNESP/FCAV Jaboticabal, São Paulo, Brazil), a female dog of 14-year-old, $6 \mathrm{~kg}$, was admitted showing 15 days of right pelvic limb lameness.

Clinical Exam Findings. On the first appointment day, the client reported as main complaint pelvic limb lameness and a lump located in the right tibia. The mass was adhered, alopecic and ulcerated, measured by a pachymeter $8.8 \times 6.8$ $\times 6.3 \mathrm{~cm}$ (Figure 1 ).
La definición de osteosarcoma perióstico es desafiante. Un diagnóstico preciso requiere la correlación de la evaluación clínica, radiográfica e histopatológica. Es esencial excluir el osteosarcoma perióstico del osteosarcoma central con extensión perióstica, el osteosarcoma de superficie de alto grado y el osteosarcoma paróstico (1).

El patrón histopatológico del osteosarcoma central incluye la producción de hueso osteoide o inmaduro por osteoblastos malignos. Sin embargo, tanto la cantidad como la calidad de la matriz osteoide pueden variar mucho de un tumor a otro (8). La característica básica del osteosarcoma de superficie de alto grado es el sarcoma de crecimiento rápido que surge del tejido perióstico $(3,6)$. Histopatológicamente, el osteosarcoma parostal se eleva desde la capa fibrosa externa del periostio y revela características del osteosarcoma osteoblástico de grado I o II, asemejándose a la displasia (4).

En todos los tipos de osteosarcoma, se puede prescribir quimioterapia adyuvante para proporcionar apoyo farmacológico después de los procedimientos quirúrgicos (7). Al mismo tiempo, el valor de los tratamientos adyuvantes para el osteosarcoma perióstico es incierto $(9,10)$. En consecuencia, se han realizado varios estudios para evaluar si el tiempo de supervivencia libre de los perros con osteosarcoma puede prolongarse mediante quimioterapia adyuvante $(1,4,9,11)$. Sin embargo, debido a la rareza del tumor, los datos disponibles son insuficientes para apoyar dicho tratamiento $(9,12)$. Los últimos informes mostraron la eficacia de pocos medicamentos citostáticos, como carboplatino, cisplatino y doxorrubicina (1).

En oncología veterinaria, el osteosarcoma perióstico en perros está poco descrito. Igualmente importante, el número de casos reportados que describen los hallazgos histopatológicos y el tiempo de supervivencia es restringido. Un informe descriptivo que muestra la apariencia clínica y el diagnóstico de este tumor raro en perros con el fin de estimular una investigación precisa fue el propósito de este informe.

Anamnesis. En el Hospital Veterinario de la Facultad de Ciencias Agrarias y Veterinarias de la Universidad del Estado de São Paulo (UNESP/ FCAV Jaboticabal, São Paulo, Brasil), una perra de 14 años, de $6 \mathrm{~kg}$, fue admitida mostrando 15 días de cojera en el miembro pélvico derecho.

Hallazgos de los exámenes clínicos. En el primer día de la cita, la cliente reportó como queja principal la cojera de las extremidades pélvicas y un bulto localizado en la tibia derecha. La masa fue adherida, alopécica y ulcerada, medida con un paquímetro de $8.8 \times 6.8 \times 6.3$ $\mathrm{cm}$ (Figura 1). 


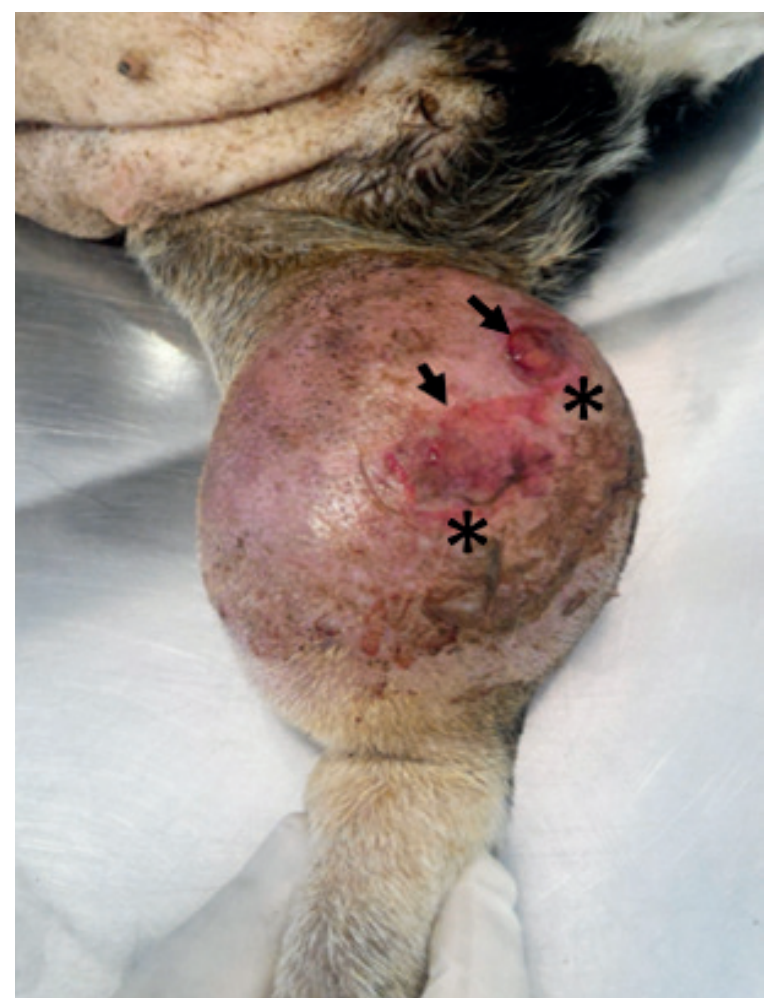

Figure 1. Periosteal osteosarcoma of the right tibia in a 14 year old female, mongrel dog. The tumor shows areas of ulceration (arrows) and a large erythematous area $(*)$. Notice two small-ulcerated areas. The photo was taken on the first appointment day.

During the physical examination, a heart murmur $(4 / 6)$ was observed. Thereafter, the dog was referred to the Veterinary Cardiology Service at the same hospital. The diagnosis was mitral valve endocardiosis and cardiac insufficiency (II) and the appropriate treatment started with client's agreement.

Diagnostic aids used. Further examinations were performed to rule out other systemic alterations. The patient was submitted for blood count analysis, dosage of biochemical enzymes (creatinine and alanine aminotransferase ALT) and abdominal ultrasonography, without alterations. The cytological examination of the mass located in the right pelvic limb suggested round cell tumor.

The dog did not show any other changes related to the skeletal system. During the orthopedic examination, the dog demonstrated moderate pain in the right pelvic limb. Neurological examination revealed no changes.

The dog was referred for Diagnostic Imaging Service at the same hospital. Thoracic radiographs
Durante el examen físico, se observó un soplo cardíaco (4/6). Posteriormente, el perro fue remitido al Servicio de Cardiología Veterinaria del mismo hospital. El diagnóstico fue endocardiosis de la válvula mitral e insuficiencia cardíaca (II) y el tratamiento apropiado comenzó con el acuerdo del cliente.

Ayudas diagnósticas utilizadas. Se realizaron exámenes adicionales para descartar otras alteraciones sistémicas. La paciente fue sometida a análisis de hemograma, dosificación de enzimas bioquímicas (creatinina y alanina aminotransferasa - ALT) y ecografía abdominal, sin alteraciones. El examen citológico de la masa localizada en el miembro pélvico derecho sugirió un tumor de células redondas.

El perro no mostró ningún otro cambio relacionado con el sistema esquelético. Durante el examen ortopédico, el perro demostró dolor moderado en el miembro pélvico derecho. El examen neurológico no reveló cambios.

El perro fue referido para el Servicio de Diagnóstico por Imágenes en el mismo hospital. Se realizaron radiografías torácicas en tres vistas (lateral derecho e izquierdo, ventrodorsal) y los hallazgos fueron consistentes con la edad del perro.

La vista lateral de la tibia derecha mostró una reacción periostática proliferativa y lítica, predominantemente proliferativa en el tercio distal de la tibia y el astrágalo derecho, excediendo la línea articular. Posteriormente, un área aumentada de masa de tejido blando, con apariencia homogénea adyacente al tercio distal de la tibia y tarso derecho y se observó pérdida de trabeculación ósea (Figura 2).

Basándose en los signos clínicos, el análisis citológico y los exámenes radiográficos, el diagnóstico presuntivo fue osteosarcoma. El diagnóstico histopatológico fue osteosarcoma perióstico con márgenes libres. No se encontraron células tumorales en los respectivos ganglios linfáticos poplíteos e inguinales de la extremidad afectada.

La medida de la masa era de $8.8 \times 6.8 \times 6.3 \mathrm{~cm}$. Las muestras se fijaron en formalina neutralizada al $10 \%$ y se transfirieron a una solución de ácido fórmico para su descalcificación. Después de tres días de descalcificación, las muestras de tejido fueron procesadas, incrustadas en parafina, seccionadas en cinco $\mu \mathrm{m}$ (micrómetros) y teñidas con Hematoxilina y Eosina (HE) para su evaluación histológica por el profesor responsable del Departamento de Patología Veterinaria.

La evaluación histopatológica reveló tejido que presentaba proliferación neoplásica de células mesenquimales originadas en el periostio que se extendían a tejidos blandos adyacentes, 
in three views (right and left lateral, ventrodorsal) were performed and the findings were consistent with the age of the dog.

The lateral view of the right tibia showed proliferative and Iytic periosteal reaction, predominantly proliferative in the distal third of the tibia and right talus, exceeding the articular line. Beyond an increased area of soft tissue mass, with homogeneous appearance adjacent to the distal third of the tibia and right tarsus and loss of bone trabeculation was observed (Figure 2).

Based on the clinical signs, cytological analysis, and radiographic examinations the presumptive diagnosis was osteosarcoma. The histopathological diagnosis was periosteal osteosarcoma with free margins. It was not found tumor cells in the respective popliteal and inguinal lymph node of the affected limb.

The measure of the mass was $8.8 \times 6.8 \times$ $6.3 \mathrm{~cm}$. The samples were fixed in $10 \%$ neutral buffered formalin and transferred to a formic acid solution for decalcification. After three days of decalcification, the tissue samples were processed, paraffin embedded, sectioned at five $\mu \mathrm{m}$ (micrometer) and stained with Haematoxylin and Eosin (HE) for histologic evaluation by the responsible professor of the Veterinary Pathology Department.

Histopathological evaluation revealed tissue showing neoplastic proliferation of mesenchymal cells originated from the periosteum that extended to adjacent soft tissue, with high cellularity, poorly demarcated, unencapsulated and infiltrative growth pattern. Through histopathological analysis, the tumor cells were between an amorphous material. The presence of areas of mineralization was also observed (poorly differentiated osteoid matrix). Singly, the cells had distinct borders, the cytoplasm was elongated and rounded, moderately and discretely acidophilic. The nuclei were elongated, hyperchromatic, with densely clustered chromatin with the single and evident nucleolus. Nuclear alterations (anisokaryosis, anisocytosis, and karyomegaly) were described. The mitotic figures were common (18 in 10 field of great increase). Few multinucleated cells (osteoclasts) were also noticed (Figure 3 ).

Treatment approach. Due to these findings, surgery was the first method of treatment and pelvic limb amputation was suggested to the client. The surgery was performed with no complications and the entire pelvic limb was sent to the Department of Veterinary Pathology of the School of Agrarian and Veterinary Sciences (FCAV/UNESP).

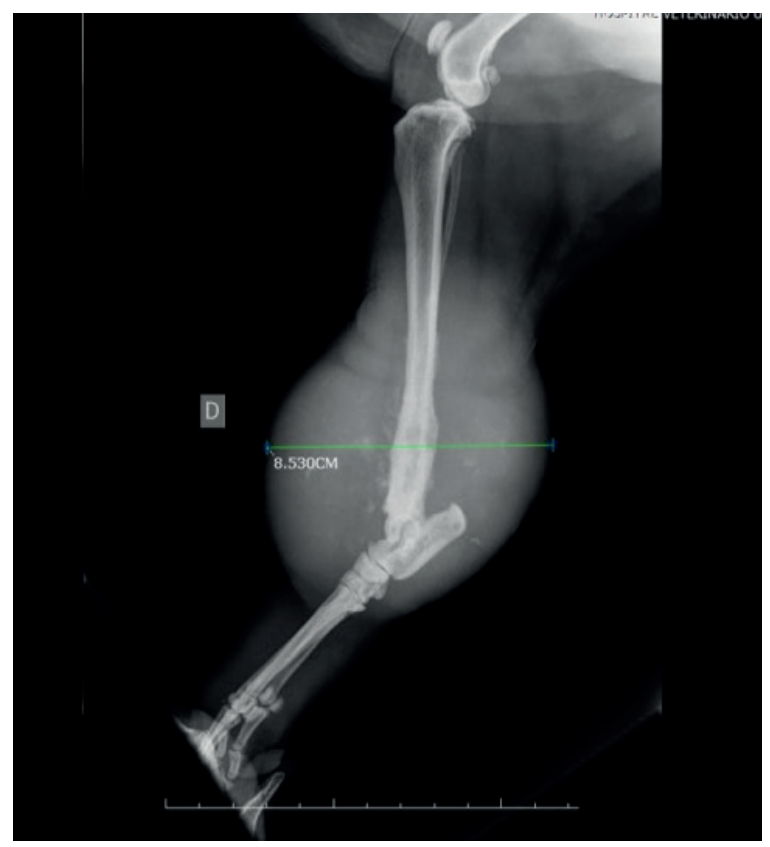

Figure 2. Lateral radiograph of periosteal osteosarcoma involving the canine right tibia. The tumor displays an active periosteal reaction and homogeneous soft tissue mass adjacent on the distal third of the tibia and is consistent with an aggressive bone lesion.

con un patrón de crecimiento celular alto, mal demarcado, no encapsulado e infiltrante. A través del análisis histopatológico, las células tumorales estaban entre un material amorfo. También se observó la presencia de áreas de mineralización (matriz osteoide poco diferenciada). Por separado, las células tenían bordes distintos, el citoplasma era alargado y redondeado, moderada y discretamente acidófilo. Los núcleos eran alargados, hipercromáticos, con cromatina densamente agrupada con el nucleolo único y evidente. Se describieron alteraciones nucleares (anisocitosis, anisocitosis y cariocomegalia). Las figuras mitóticas eran comunes (18 en 10 campos de gran aumento). También se observaron pocas células multinucleadas (osteoclastos) (Figura 3).

Enfoque de tratamiento. Debido a estos hallazgos, la cirugía fue el primer método de tratamiento y se sugirió la amputación de la extremidad pélvica a la clienta. La cirugía se realizó sin complicaciones y todo el miembro pélvico fue enviado al Departamento de Patología Veterinaria de la Facultad de Ciencias Agrarias y Veterinarias (FCAV/UNESP).

Después de la explicación del informe histopatológico, el cliente se negó a la quimioterapia adyuvante y los exámenes de seguimiento. El cliente ha elegido el cuidado 


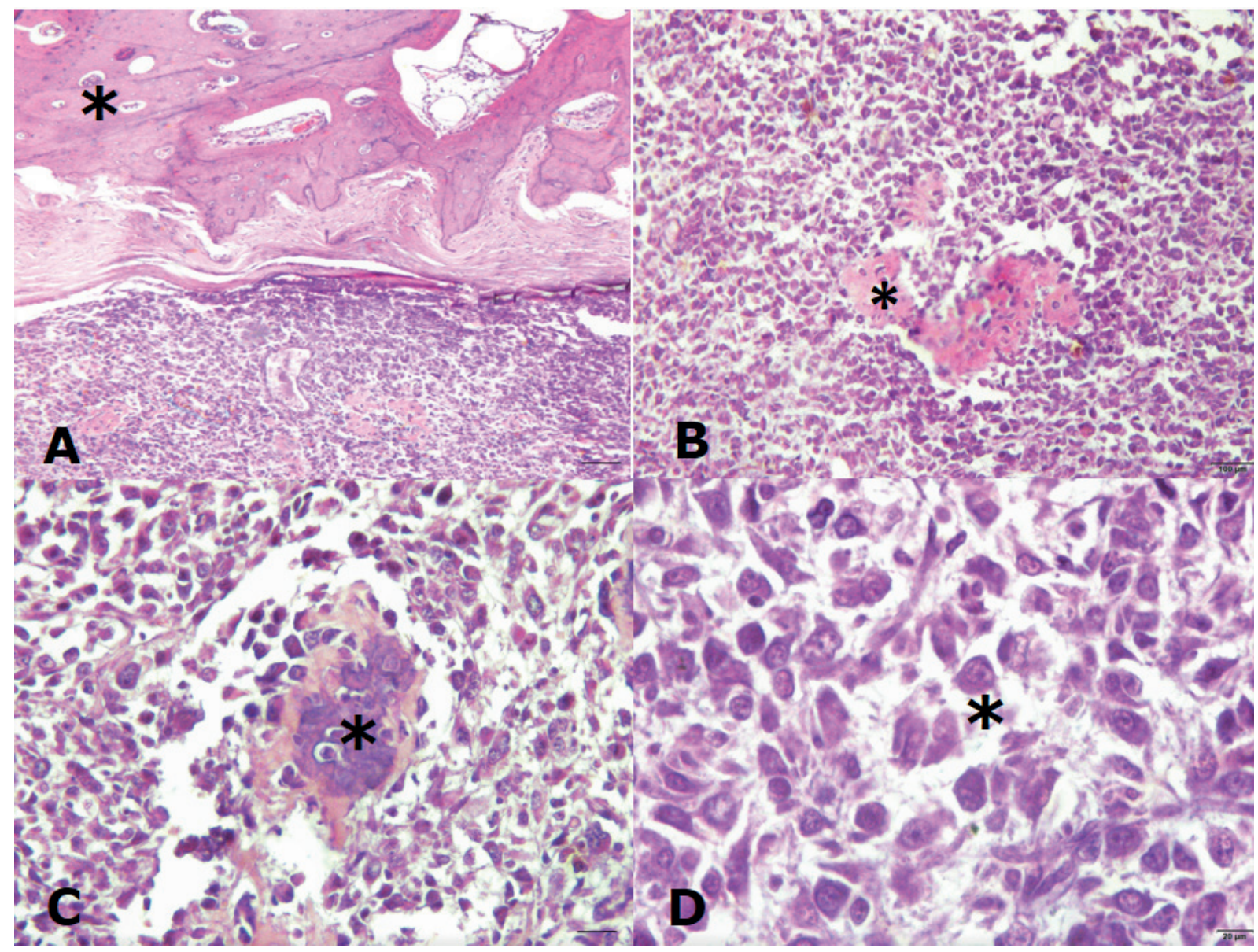

Figure 3. Photomicrography of a sample of canine bone tissue showing neoplastic mesenchymal proliferation, originated in bone cells of a 14-year-old female, mongrel dog. 3 A: Periosteal array of tumor cells. Histopathology showing areas of cartilage with eosinophilic deposits of osteoid (*), bar $50 \mu \mathrm{m} .3 \mathbf{B}$ : Detail of area with bone matrix production by tumor cells, note the island of osteoid mineralization (*), bar $200 \mu \mathrm{m} .3$ C: Area showing differentiation of young bone tissue (*), bar $100 \mu \mathrm{m} .3$ D: Higher magnification of the same tumor. Morphology of tumor bone cells, notice evident polymorphism cell (*), bar $400 \mu \mathrm{m}, \mathrm{HE}$.

After the explanation of histopathological report, the client declined to the adjuvant chemotherapy and the follow-up examinations. The client has chosen for palliative care based on medication for pain relief.

Thoracic radiographs and ultrasonography were performed during the time of clinical follow-up without evidence of metastatic disease or new lumps. The dog had a nine-month survival free time from diagnosis.

\section{DISCUSSION}

Considering the mass appearance, size, evolution time, the age of the dog, the anatomical position and the physical examination, osteosarcoma was suspected initially. Furthermore, in this case, the paliativo basado en la medicación para el alivio del dolor.

Se realizaron radiografías torácicas y ultrasonografías durante el tiempo de seguimiento clínico sin evidencia de enfermedad metastásica o nuevos bultos. El perro tuvo un tiempo libre de supervivencia de nueve meses desde el diagnóstico.

\section{DISCUSIÓN}

Teniendo en cuenta el aspecto de la masa, el tamaño, el tiempo de evolución, la edad del perro, la posición anatómica y el examen físico, se sospechó inicialmente la presencia de osteosarcoma. Además, en este caso, los hallazgos radiográficos sugieren la presencia 
radiographic findings suggested the presence of an inflammatory process or a bone tumor, especially due to the presence of periosteal reaction seen in this type of tumor.

In humans, the radiographic findings were classified in five parameters (tumor matrix, periosteal response, cortex underlying the lesion, presence of soft tissue component, and integrity of the medullary cavity (13). In the present case report, the parameters described above were also evaluated and only the medullary cavity revealed no alterations. Our findings were in line to those described by other authors.

Periosteal osteosarcoma is an uncommon bone tumor with insufficient data on long-term followup. In humans, a large study with periosteal osteosarcoma described patients with a free survival time of $83 \%$ over than 10 years $(4,12)$. The survival rate of the dog described in this case report was nine months after diagnosis, which is considered satisfactory in this species. However, the number of cases reported, and follow-up information were minimal to determine a rate of survival time in dogs. The present case added the follow up information on this type of tumor, as we consider this information relevant. In the future, new cases would be compiled with the aim of evaluating this parameter, isolated or in association with others.

Periosteal osteosarcoma and other bone tumors were diagnosed based on the radiographic and histopathologic analysis with no medullary involvement of the tumor (3). Other authors have described periosteal osteosarcoma with microscopic or gross medullary involvement $(3,4)$. Although the radiographic and histopathologic features of this tumor were consistent, they cannot be diagnosed alone. When medullary involvement is present, it is not possible to distinguish periosteal osteosarcoma from classic chondroblastic osteosarcoma, which has broken through the cortex and shows a surface mass, primarily (12).

In humans, three typical radiographic and histopathological features of periosteal osteosarcoma were pointed. The first one is a periosteal mass attached to the cortex of the affected diaphysis of long bones. The second one is the presence of Codman's Triangle formations in the cortex of bone tumor. The Codman's triangle is a triangular area of new subperiosteal bone that occurs when an injury (often a tumor) raises the periosteum from the bone. The third one is the size of the main tumor at the periosteal lesion that is larger than the intramedullary lesion. The observation of chondroblastic matrix de un proceso inflamatorio o un tumor óseo, especialmente debido a la presencia de reacción periostática observada en este tipo de tumor.

En humanos, los hallazgos radiográficos se clasificaron en cinco parámetros (matriz tumoral, respuesta perióstica, corteza subyacente a la lesión, presencia del componente de tejido blando e integridad de la cavidad medular (13). En el presente informe de caso, también se evaluaron los parámetros descritos anteriormente y sólo la cavidad medular no reveló alteraciones. Los resultados coincidieron con los descritos por otros autores.

El osteosarcoma perióstico es un tumor óseo poco frecuente con datos insuficientes sobre el seguimiento a largo plazo. En humanos, un gran estudio con osteosarcoma perióstico describió pacientes con un tiempo de supervivencia libre del $83 \%$ durante más de 10 años $(4,12)$. La tasa de supervivencia del perro descrito en este informe de caso fue de nueve meses después del diagnóstico, lo que se considera satisfactorio en esta especie. Sin embargo, el número de casos reportados y la información de seguimiento fueron mínimos para determinar una tasa de tiempo de supervivencia en los perros. El presente caso añadió la información de seguimiento sobre este tipo de tumor, ya que consideramos que esta información es relevante. En el futuro, se recopilarán nuevos casos con el objetivo de evaluar este parámetro, de forma aislada o en asociación con otros.

El diagnóstico del osteosarcoma perióstico y otros tumores óseos se basó en el análisis radiográfico e histopatológico sin compromiso medular del tumor (3). Otros autores han descrito el osteosarcoma perióstico con compromiso medular microscópico o macroscópico $(3,4)$. Aunque las características radiográficas e histopatológicas de este tumor fueron consistentes, no pueden ser diagnosticadas por sí solas. Cuando existe compromiso medular, no es posible distinguir el osteosarcoma perióstico del clásico osteosarcoma condroblástico, que ha atravesado la corteza y muestra una masa superficial, principalmente (12).

En humanos, se señalaron tres características radiográficas e histopatológicas típicas del osteosarcoma perióstico. La primera es una masa perióstica adherida a la corteza de la diáfisis afectada de los huesos largos. La segunda es la presencia de las formaciones del Triángulo de Codman en la corteza del tumor óseo. El triángulo de Codman es un área triangular de hueso subperióstico nuevo que ocurre cuando una lesión (a menudo un tumor) eleva el periostio desde el hueso. El tercero es el tamaño del tumor principal en la lesión perióstica que es más grande que la lesión intramedular. La observación de la matriz condroblástica con la 
with the osteoid formation and histopathological grade II or III were considered the foremost lesions on histopathological examination in the patient of the case (3).

Previously in humans' studies, it was suggested that the anatomic position of the tumor might influence the survival time; proximal femoral lesions might show lateness through the course of disease with poorer outcomes (12). However, similar survival rates for patients with tumors located proximally or distally and in patients with femoral and non-femoral tumors were reported $(12,14)$. In one study, the anatomic position (proximal versus distal or femoral versus nonfemoral) did not influence the survival time (12). The most frequent sites of periosteal osteosarcoma was tibia, nearly $40 \%$ (7). The anatomic position seen in this case report was distal diaphysis of the right tibia and our results agreed with the previous authors. Most of the cases seen in dogs are descriptive and do not allow a study comparing the tumor anatomical position and the survival rate.

In a veterinary report, periosteal osteosarcoma had histopathologic appearance characterized by low or medium histopathologic grade, usually with ossification areas (8). Only two reports have been described this tumor in the metaphyseal surface of long bones rather than the diaphyseal surface in humans (5). In dogs, the tumor usually is in the diaphyseal region, produces dense bone matrix, and no pulmonary metastases were detected at the time of amputation (8). Additionally, there is one case report of periosteal osteosarcoma described in the scapula of an eight-year-old Arabian horse. The neoplastic proliferation of the periosteum was disseminated, starting at the distal neck of the scapula and extending distally to the metaphyseal region of the humerus (15). Considering the anatomic position and the histopathological changes, these events were identical to that observed by previous authors. The exception was the absence of the Codman's triangle and the metaphyseal location of the tumor in the horse.

Surgical treatment is the best option in cases of osteosarcomas, including the periosteal osteosarcoma (12). Surgery (either limb amputation or limb-sparing surgery) is the first method of treatment. (10). Limb-sparing surgery is an alternative method to limb amputation (2). Moreover, tumor recurrence appears in $15-25 \%$ of cases. As a result, this technique is recommended for dogs with compromising neurologic or orthopedic problems (11). In the present study, pelvic limb amputation was performed with free margins and lymph nodes formación osteoide y el grado histopatológico II o III se consideraron las lesiones más importantes en el examen histopatológico en el paciente del caso (3).

Anteriormente en estudios en humanos, se sugirió que la posición anatómica del tumor podría influir en el tiempo de supervivencia; las lesiones femorales proximales podrían mostrar tardanza a través del curso de la enfermedad con peores resultados (12). Sin embargo, se informaron tasas de supervivencia similares para pacientes con tumores localizados proximal o distalmente $y$ en pacientes con tumores femorales y no femorales $(12,14)$. En un estudio, la posición anatómica (proximal versus distal o femoral versus no femoral) no influyó en el tiempo de supervivencia (12). El sitio más frecuente de osteosarcoma perióstico fue la tibia, cerca del $40 \%$ (7). La posición anatómica observada en este informe de caso fue la diáfisis distal de la tibia derecha y nuestros resultados coincidieron con los de los autores anteriores. La mayoría de los casos observados en perros son descriptivos y no permiten un estudio que compare la posición anatómica del tumor y la tasa de supervivencia.

En un informe veterinario, el osteosarcoma perióstico tenía un aspecto histopatológico caracterizado por un grado histopatológico bajo o medio, generalmente con áreas de osificación (8). Sólo se han descrito dos informes sobre este tumor en la superficie metafisaria de los huesos largos en lugar de en la superficie diafisaria en humanos (5). En los perros, el tumor suele estar en la región diafisaria, produce una matriz ósea densa y no se detectaron metástasis pulmonares en el momento de la amputación (8). Además, hay un caso reportado de osteosarcoma perióstico descrito en la escápula de un caballo árabe de ocho años. Se diseminó la proliferación neoplásica del periostio, comenzando en el cuello distal de la escápula y extendiéndose distalmente hasta la región metafisaria del húmero (15). Considerando la posición anatómica y los cambios histopatológicos, estos eventos fueron idénticos a los observados por los autores anteriores. La excepción fue la ausencia del triángulo de Codman y la ubicación metafisaria del tumor en el caballo.

El tratamiento quirúrgico es la mejor opción en los casos de osteosarcomas, incluido el osteosarcoma perióstico (12). La cirugía (ya sea amputación de extremidades o cirugía de preservación de extremidades) es el primer método de tratamiento. (10). La cirugía de preservación de extremidades es un método alternativo a la amputación de extremidades (2). Además, la recidiva tumoral aparece en el $15-25 \%$ de los casos. Como resultado, esta técnica se recomienda para perros con problemas neurológicos u ortopédicos comprometidos (11). En el presente estudio, la amputación de 
without evidence of tumor cells and these results were confirmed in the histopathological evaluation. Nine months after diagnosis there was no evidence of metastasis or new lumps. Thoracic radiographs and ultrasound follow-up were performed every 2 months. It was not possible to establish if there was a recurrence of the tumor since the patient had an advanced age and died due to natural causes. The client has chosen for palliative care based on medication for pain relief and metronomic chemotherapy (cyclophosphamide $12.5 \mathrm{mg} / \mathrm{m}^{2}$ ), and the followup examinations.

In conclusion, the clinical evidence suggested that periosteal osteosarcoma in dogs must be treated surgically. The unusual occurrence of periosteal osteosarcoma in canine patients, the histopathological description and the free survival time were highlighted in this report. Studies involving a greater number of reported cases must be analyzed to compile additional data such as age, sex, breed, biological behavior, prognosis and free survival time on this rare tumor in dogs.

Conflicts of interest. The authors declare that they have no conflict of interest. miembros pélvicos se realizó con márgenes libres y ganglios linfáticos sin evidencia de células tumorales y estos resultados fueron confirmados en la evaluación histopatológica. Nueve meses después del diagnóstico no hubo evidencia de metástasis o nuevos bultos. Se realizaron radiografías torácicas y seguimiento ecográfico cada 2 meses. No fue posible establecer si hubo una recurrencia del tumor ya que el paciente tenía una edad avanzada y murió por causas naturales. El cliente ha optado por los cuidados paliativos basados en la medicación para el alivio del dolor y la quimioterapia metronómica (ciclofosfamida $12,5 \mathrm{mg} / \mathrm{m} 2$ ), y los exámenes de seguimiento.

En conclusión, las pruebas clínicas sugieren que el osteosarcoma perióstico en perros debe tratarse quirúrgicamente. En este informe se destaca la inusual aparición de osteosarcoma perióstico en pacientes caninos, la descripción histopatológica y el tiempo de supervivencia libre. Los estudios que involucran un mayor número de casos reportados deben ser analizados para recopilar datos adicionales como edad, sexo, raza, comportamiento biológico, pronóstico y tiempo de supervivencia libre sobre este tumor raro en perros.

Conflictos de intereses. Los autores declaran que no tienen ningún conflicto de intereses.

\section{REFERENCES}

1. Szewczyk M, Lechowski, R, Zabielska K. What do we know about canine osteosarcoma treatment? - review. Vet Res Commun. 2015; 39(1):61-67.

2. Skorupski KA, Uhl JM, Szivek A, Allstadt Frazier SD, Rebhun RB, Rodriguez CO Jr. Carboplatin versus alternating carboplatin and doxorubicin for the adjuvant treatment of canine appendicular osteosarcoma: a random. Vet Comp Oncol. 2013; 14(1):81-87.

3. Suehara Y, Yazawa Y, Hitachi K, Yazawa M. Periosteal osteosarcoma with secondary bone marrow involvement: a case report. J Orthop Sci. 2004; 9(6):646-649.

4. Cesari M, Alberghini M, Vanel $D$, Palmerini $E$, Staals E, Longhi A, Abate M, Ferrari C, Balladlli A, Ferrari S. Periosteal osteosarcoma: a single-institution experience. Cancer. 2011; 117(8):1731-1735.
5. Bertoni S, Boriani F, Laus M, Campanacci M. Periosteal chondrosarcoma and periosteal osteosarcoma two distinct entities. J Bone Joint Surg Am. 1982; 64(3):370-376.

6. Wang GD, Zhao YF, Liu Y, Jiang L, Jiang ZJ. Periosteal Osteosarcoma of the Mandible: Case Report and Review of the Literature. J Oral Maxillofac Surg. 2011; 69(6):1831-1835.

7. Liu XW, Zi Y, Xiang LB, Han TY. Periosteal osteosarcoma: a review of clinical evidence. Int J Clin Exp Med. 2015; 8(1):37-44.

8. Thompson KG, Dittmer KE. Tumors in domestic animals. Meuten DJ. (Editor) Tumor of bones. Oxford: John Wiley \& Sons, Inc; 2017.

9. Singh D, Sen R, Chaudhary S, Tripathy SK. Periosteal osteosarcoma of the calcaneum: a case report. Foot Ankle Spec. 2012; 5(2):121-133. 
10. Toledo GN, Moreira PRR. Canine periosteal osteosarcoma. J Vet Healthcare. 2017; 1(1):14-21.

11. MacDonald TL, Schiller TD (Limb-sparing surgery using tantalum metaled prosthesis in a dog with osteosarcoma of the distal radius. Can Vet J. 2010; 51(5):497-500.

12. Rose PS, Dickey ID, Wenger DE, Unni KK, Sim FH. Periosteal osteosarcoma long-term outcome and risk of late recurrence. Clin Orthop Relat Res. 2006; 453:314-317.
13. Santos LA, Murray JA, Barnett Finklestein J, Spjut HJ, Ayala AG. The radiographic spectrum of periosteal osteosarcoma. Radiol. 1978; 127(1):123-129.

14. Muir TM, Lehman TP, Meyer WH. Periosteal osteosarcoma in the hand of a pediatric patient: a case report. J Hand Surg Am. 2008; 33(2):266-8.

15. Zaruby JF, Williams JW, Lovering S. Periosteal osteosarcoma of the scapula in a horse. Can Vet J. 1993; 34:742-744. 